\title{
TECHNOLOGY CREATING A NEW HUMAN: THE ALCHEMICAL ROOTS OF TRANSHUMANIST IDEAS
}

\author{
Kurmo Konsa \\ Associate Professor \\ Institute of History and Archaeology \\ University of Tartu, Estonia \\ kurmo.konsa@ut.ee
}

\begin{abstract}
The aim of this article is to present a critical discussion of the influence of technology on humans and culture in contemporary Western society. Transhumanism is a philosophical and social movement that believes that the essential features of human life could be transformed and enhanced by applications of science and technology. In this article, I will compare transhumanist ideas about perfecting humans to the views of Roger Bacon, one of the representatives of European mediaeval alchemy. Such a treatment provides a historical background for transhumanist ideas and helps answer the moral and philosophical problems that humans are faced with due to modern technological development. Despite the fact that several transhumanist theoreticians treat it as a secular alternative to religious ideas, we can see that Christian eschatology plays a major role. Both in alchemy and transhumanism, scientific and theological aspects have been inseparably intertwined. Transhumanism can be seen as a continuation of the alchemical project in the twenty-first century. Modern science has added new tools to realise the goal of alchemical perfection. Transhumanism characterises very well the fact that the practices and theories of alchemy changed over time and adapted to changed contexts.
\end{abstract}

Keywords: alchemy, Christian eschatology, immortality, Roger Bacon, technological singularity, transhumanism

\section{INTRODUCTION: HUMANS AND TECHNOLOGY}

Human society is largely based on tools and technologies that are constantly being developed (Ferkiss 1969: 49). Throughout history, new technologies have continuously been developed and applied, and prevailing technologies supplanted by new ones. Technology on its own does not change society, of course; however, technology is intertwined with the social and societal systems. When existing technologies are replaced by new ones, a ripple of change affects the 
entire complex system, encompassing production, marketing, advertising, and consumption. There is no doubt that we are living in the age of technology, and although in one way or another technology has always been an inseparable part of human culture, it has never defined human nature to such an extent. Technology plays a crucial role in the relationship between mankind and nature, as it is technology that connects humans with nature, acting as a type of intermediary (Smith 1996). Technology simultaneously shapes and describes the relationship that humans have with the surrounding environment. We might say that technology is a tool to naturalise culture and to culturise nature.

The question of the relationship between technology and mankind was by no means invented in the twentieth century; it has a long history and most of the problems that we encounter have been discussed before. The majority of arguments that are used in debates over whether and to what extent we can intervene in nature originate from as early as antiquity and the Middle Ages. In early European literature there are numerous stories of how humans tried to imitate the gods. However, even if they succeeded, the stories usually end with revenge by the gods and the destruction of what humans created.

The human body and mind are, to an increasing extent, occupied by technology, the end result of which in the near future might be the emergence of a new human race that lives in a perfect symbiosis with machines. This perspective is proposed by the transhumanist movement. In many respects, these projects resemble science fiction, from where they often derive their ideas. These projects are a sign of a changing societal and political climate. Perhaps this is an indication that we are willing to let go of the notions of human nature and humanity that we have held up to now. Since the nature of humans will change radically, likewise the understanding of what it means to be a human being will change.

One of the most important fields that dealt with the relationship between the natural and the artificial in the Middle Ages and in the early modern period was undoubtedly alchemy. Alchemy is first and foremost known as a practice that studied the transmutation of metals. In a broader sense, the questions that interested alchemists were related to the study of ethical and ontological borders between the natural sciences and technology. The quintessential questions underpinning alchemy were concerned with what was natural, what was artificial, and how humans could perfect nature with the help of technology. Assuredly, these are problems that also have crucial importance today. In the alchemical literature, clear parallels can be found to contemporary debates about whether genetic engineering should be allowed and whether it is reasonable. The technologies may be new, but they nevertheless carry on the old tradition. In the beginning, alchemists' attempts to imitate nature focused mainly on creating precious metals (gold and silver) and precious gemstones; later, however, their aims became more diverse and included the artificial creation of human life. 
Transhumanism is deeply rooted in Western Christian culture, including alchemy. The Christian origin of transhumanism has been noted by several researchers (Cady 2011; Noble 1997). The reflections of other religions, such as Buddhism (Maher 2014), Judaism (Samuelson \& Tirosh-Samuelson 2011), Islam (Mahootian 2011; Mavani 2014), Orthodoxy (Clay 2011), and Gnosticism (Krueger 2005; Pugh 2017) in transhumanism have also been studied. There has been almost no discussion of alchemy in this respect.

The aim of this article is to present a critical discussion of the influence of technology on humans and culture in contemporary Western society. Since transhumanism has become the school of thought that discusses the biological future of humans in most detail, I will focus on this. In this article, I will compare transhumanist ideas about perfecting humans and the end of the world to the views of Roger Bacon, one of the representatives of European mediaeval alchemy. Such a treatment provides a historical background to transhumanist ideas and helps deal with the moral and philosophical problems that humans are faced with due to the development of modern technology. It also helps assess the affect that transhumanist thought has on contemporary culture.

First, I will give an overview of how the transhumanist movement emerged, and of the ideas that constitute its background; I will then provide a brief introduction to alchemy and discuss the works of Roger Bacon, one of the representatives of European medieval alchemy, in closer detail. In the discussion section, I will focus on the parallels between mediaeval alchemy and contemporary transhumanism, and analyse their connections within the wider cultural context.

\section{TRANSHUMANISM}

Transhumanism (abbreviated as $\mathrm{H}+$ or $\mathrm{h}+)^{1}$ has become one of the most significant contemporary schools of thought that analyses the effect of technology on humans and human society. Transhumanism has been defined in varying terms in the research literature, with all the definitions underpinned by the idea of the mental and physical abilities of mankind being changed and perfected using different technological methods. ${ }^{2}$ Supporters of the transhumanist view believe that we should use genetic engineering, nanotechnology, information technology, etc., to augment human evolution as a biological species to a significant extent, thereby lifting mankind to a new developmental stage. Transhumanism considers it inevitable that existing humans need to be redefined and surpassed, and that we need to move towards a new species. New technologies will change the world to such an extent that our descendants will no longer be humans, but posthumans. James Hughes, one of the leading transhumanists, has expressed this idea as follows: 
Life spans will extend well beyond a century. Our senses and cognition will be enhanced. We will gain control over our emotions and memory. We will merge with machines, and machines will become more like humans. These technologies will allow us to evolve into varieties of 'post humans' and usher us into a 'transhuman' era and society. (Hughes 2004: xii)

Although it is very hard to determine how exactly posthumans will differ from contemporary humans, this difference is nevertheless one of the key ideas of transhumanism. Information technology, the merging of humans and different technological devices, genetic modifications, and enhancement of mental abilities are the main methods proposed for human modification. Posthumans will have new and perfected physical and cognitive abilities, and will suffer neither illness nor death. Nick Bostrom, one of the leading philosophical interpreters of transhumanism, defines it as "a way of thinking about the future that is based on the premise that the human species in its current form does not represent the end of our development but rather a comparatively early phase" (Bostrom 2003).

The key ideas of transhumanism were first introduced in an essay by a renowned British geneticist John Burdon Sanderson Haldane (1892-1964), entitled "Daedalus: Science and the Future" (1924), in which he predicted that the application of sciences to change the biology of humans would reap great benefits in the future. He was also very interested in the application of eugenics, ectogenesis ${ }^{3}$ and genetics to improve people's health and enhance their intelligence. Such ideas suffered an understandable setback after World War II, because of Nazis' abuse of the ideas of eugenics. The term 'transhumanism' was first adopted by biologist Julian Huxley (1887-1975), who used it in the title of his article published in 1957. He also called transhumanism "evolutionary humanism" and described its ideas in the following manner:

Up till now human life has generally been, as Hobbes described it, 'nasty, brutish and short'; the great majority of human beings (if they have not already died young) have been afflicted with misery... we can justifiably hold the belief that these lands of possibility exist, and that the present limitations and miserable frustrations of our existence could be in large measure surmounted... The human species can, if it wishes, transcend itself-not just sporadically, an individual here in one way, an individual there in another way, but in its entirety, as humanity. (Huxley 1957: 14)

Similar ideas were also presented by psychologist Abraham Maslow, the leader of the Human Potential Movement, who coined the term 'metahuman'. A metahuman is a person who surpasses the level of a normal human being in the course of self-actualising and becomes godlike (Maslow 1971: 274). 
The formal transhumanist movement started at the beginning of the 1980s at the University of California in Los Angeles, which also became the leading centre of transhumanism. In 1988, the first issue of the journal Extropy: The Journal of Transhumanist Thought, was published by the philosopher Max More and Tom Bell (aka T.O. Morrow); and in 1991, the Extropy Institute was founded. The founding of this institute is considered to be the institutional establishment of transhumanist ideas. ${ }^{4}$ The institute organised numerous international conferences, and, more importantly, its mailing list became a venue for discussion of transhumanist ideas. In 1998, philosophers Nick Bostrom and David Pearce founded an international non-profit association called the World Transhumanist Association (WTA), the aim of which is to spread transhumanist thought so that it will become an integral part of scientific research and public politics. In 1998, the "Transhumanist Declaration", prepared by the transhumanist activists was published. The declaration expressed the main transhumanist positions in relation to the technological perfection of humans:

1. Humanity stands to be profoundly affected by science and technology in the future. We envision the possibility of broadening human potential by overcoming aging, cognitive shortcomings, involuntary suffering, and our confinement to planet Earth.

2. We believe that humanity's potential is still mostly unrealized. There are possible scenarios that lead to wonderful and exceedingly worthwhile enhanced human conditions.

7. We advocate the well-being of all sentience, including humans, non-human animals, and any future artificial intellects, modified life forms, or other intelligences to which technological and scientific advance may give rise. 8. We favour allowing individuals wide personal choice over how they enable their lives. This includes use of techniques that may be developed to assist memory, concentration, and mental energy; life extension therapies; reproductive choice technologies; cryonics procedures; and many other possible human modification and enhancement technologies.

In 2006, the Extropy Institute closed and in 2008 the World Transhumanist Association was renamed Humanity+. Numerous organisations deal with transhumanism today, such as the Foresight Institute, the Immortality Institute, the Institute for Ethics and Emerging Technologies, and the Singularity Institute for Artificial Intelligence, to give a few examples. The academic discipline of Future Studies has also emerged. Despite the diverse nature of the transhumanist movement, it is characterised by shared themes such as the constant development of mankind, the perfection of humans by technological devices and methods, the constant increase in human well-being and happiness, and 
questions about longevity and practical immortality. All these topics are understandably very important, not only from a scientific perspective, but also from the viewpoint of people's everyday lives and futures. Transhumanism represents a trend that is gaining more and more importance in the development and the lore of contemporary Western societies. It is a cultural reaction to the accelerated technological progress and the triumph of science.

\section{ALCHEMY}

It is not easy to provide an exact definition of alchemy, since it is a phenomenon that has existed for a very long time and in very different cultural contexts. ${ }^{5}$ Without going into diverse contemporary definitions, I will present a definition of alchemy from the book titled The Mirror of Alchimy (Speculum Alchemiae), the author of which was erroneously thought to have been Roger Bacon. It is most likely that the book was written by an anonymous author somewhere between the thirteenth and the fifteenth century. However, since Roger Bacon has an important role to play in my current discussion, I chose the definition of alchemy from this treatise:

In many ancient Books there are found many definitions of this Art, the intentions whereof we must consider in this Chapter. For Hermes said of this Science: Alchemy is a Corporal Science simply composed of one and by one, naturally conjoining things more precious, by knowledge and effect, and converting them by a natural commixtion into a better kind. A certain other said: Alchemy is a Science, teaching how to transform any kind of metal into another: and that by a proper medicine, as it appeared by many Philosophers' Books. Alchemy therefore is a science teaching how to make and compound a certain medicine, which is called Elixir, the which when it is cast upon metals or imperfect bodies, does fully perfect them in the very projection. (Bacon 1597: Ch I)

As is evident in this quote, the author of the treatise describes alchemy as a science that deals with making less precious items more precious. The most obvious example of such transmutation is transforming metals into precious metals, although in fact this applies to all natural objects. This is science, but it is also clearly a form of art, meaning that it does not only concern itself with the process of transmutation but also applies it in practice. Owing to the practical aspect, alchemy has been related to metallurgy, goldsmithery, jewellery art, and glass art.

When discussing the theory and practice of alchemy in very broad terms as the study and influence of the processes of change that take place in nature, 
we can distinguish three cultural-geographical centres where alchemy evolved. Western alchemy started in the Greek-Egyptian culture (approximately 3rd century AD) and spread to North Africa, the Middle East, the Byzantine Empire, and Europe. In Western alchemy, prolonging life and achieving immortality were topics left practically untreated both in antiquity and the Middle Ages. Somewhat unexpectedly, these themes appeared in the West in the late Middle Ages, in the thirteenth century, in the writings of Roger Bacon and John of Rupescissa, both members of the Franciscan order.

\section{ROGER BACON'S TREATMENT OF IMMORTALITY}

Not much is known about the life of Roger Bacon. ${ }^{6}$ He was born around 1214/1220 to a relatively wealthy family in England. After having completed his studies at Oxford, he worked there as a lecturer. He went on to complete a master's degree at the University of Paris and also taught there. He had a wide range of interests, from mathematics and philosophy to optics, alchemy, and magic. Bacon himself divided his life into two parts: first, his secular career as a scholar; and later, his life as a Franciscan friar, devoted to "the search of true wisdom" (Antolic-Piper n.d.). He probably joined the Franciscan order in 1256. In 1263 or 1264, he met Cardinal Guy Folques and discussed his scientific views with the cardinal. The cardinal became Pope Clement IV the following year and immediately gave Bacon the directive to write works explaining his ideas in more depth. In 1268, Roger Bacon completed his Opus Tertium (Third Work). Indeed, this was a part of a larger body of texts that he wrote at the demand of Pope Clement IV. Opus Tertium was an overview of the work Opus Minus (Lesser Work), which was in turn a summary of Opus Majus (Major Work). ${ }^{7}$ The works dealt with philosophy, theology, and also alchemical topics.

Bacon divided alchemy into speculative and operative alchemy. Operative alchemy involved carrying out experiments; theoretical explanation was not the main focus. Operative alchemy was practiced by experienced alchemists who nevertheless failed to understand the main aim of alchemy. According to Bacon, speculative alchemy was practiced by only a few alchemists who knew how to use alchemy both with lifeless bodies and living substances. Indeed, the human body was the main subject of speculative alchemy (Bacon 1912: 88; Newman 1997). Bacon also considered astrology to be very important, and believed that the heavenly bodies affected earthly bodies as well as the physiology of the human body. The effect of heavenly movements on humans changed constantly and combined with the humoral structure of the human body, which Bacon called the complexion of the body. The effect that stars and humours have on human behaviour is important. Therefore, the balance of humours in the 
body is to an extent determined by the position of the stars at the time of birth. Bacon did not deny that people had free will, since it would have contradicted Christian doctrine, but he claimed that these influences made people inclined to certain deeds. Bacon hoped to weaken negative influences and strengthen positive influences with the help of astrology and alchemy.

Bacon held the view that it was possible to prolong a person's life and improve their health if the right tools were used. He based his arguments mainly on the Bible (Gen:5), where it is written that people lived longer before the great flood, even up to a thousand years. Bacon thought this to be the natural lifespan of a human being, and that in his contemporary world, people lived much shorter lives due to their sins and corrupt way of life. He wrote:

The Possibility of Prolongation of Life is confirmed by this, that Man is naturally immortal, that is, able not to dye: And even after he had sinned, he could live near a Thousand Years, afterwards by little and little the Length of his Life was abbreviated. Therefore it must needs be, that this Abbreviation is Accidental; therefore it might be either wholly repaired, or at least in part. But if we would but make Enquiry into the Accidental Cause of this Corruption, we should find, it neither was from Heaven, nor from ought but want of a Regiment of Health. For in as much as the Fathers are corrupt, they beget Children of a corrupt Complexion and Composition, and their Children from the same Cause are corrupt themselves: And so Corruption is derived from Father to Son, till Abbreviation of Life prevails by Succession. Yet for all this it does not follow, that it shall always be cut shorter and shorter... (Bacon 1683: 63-64)

Since Bacon believed the shortening of people's lifespans to be an accidental process conditioned by external factors, not a characteristic feature of humans, then lifespan could also be prolonged. In order to do this, he intended to use primarily alchemical methods. Bacon was the first person in the Western alchemical tradition to write about prolonging lives. He recommended an alchemical elixir as the main tool to prolong one's life. ${ }^{8}$ A balance of elements is the theoretical foundation of the alchemic elixir:

If the elements should be prepared and purified in some mixture, so that there would be no action of one element on another, but so that they would be reduced to pure simplicity, the wisest have judged that they would make a perfect medicine. (Matus 2017: 46)

There is no such medicine found in nature; it can only be prepared through alchemy. 
According to alchemical theory, all bodies are composed of four elements: fire, water, earth, and air. All natural bodies emerge from these elements. The elements themselves can never be found in perfectly pure form, they always contain some of each other to a smaller or a larger extent. The differences between all things can be attributed to the occurrence of the elements in distinct proportions (Principe 2013: 37-38). When combined in the human body, the four elements form bodily fluids, or humours. This theory of humours was systematised by the physician Galen of Pergamon (AD 129-ca. 200 (Gruman 2003 [1966]: 21-22). In simple bodily fluids, there is one dominant element with its corresponding qualities. The bodily fluids are: yellow bile, dominated by fire; black bile, dominated by earth; blood, dominated by air; and phlegm, dominated by water. According to Bacon, the humours found in the body were the result of a combination of these primary bodily fluids. For instance, the phlegm found in the human body was a secondary bodily fluid composed of all four humours, although the dominant humour was primary phlegm. Bacon found that primary humours could also be found in bodies other than animals (Newman 1997).

According to the humoral theory, there is a balance of humours in a healthy human being known as eucrasia. A medicine in which the elements are balanced can recreate the balance of the bodily humours by cleansing the body of excessive fluids and replacing what is lacking. Bacon presented the first man, Adam, as the most convincing argument to support his theory. Adam's body, like all earthly bodies, was made up of elements and bodily fluids; decomposition and ageing were the result of these bodily fluids affecting each other. As with everyone who has existed since, Adam had to balance the humours through food. In normal food, the elements are not balanced and therefore one cannot balance one's bodily fluids to perfection. Adam, however, ate the fruits of the tree of life in the Garden of Eden; his body retained its immortality because in this fruit, the elements were in perfect balance. Adam's body was, of course, more perfect than the bodies of the people who have come since. Yet every human body is immortal in nature, capable of existing endlessly, if only the composition of the body remains in perfect balance. Here, Bacon once again relies on the Bible and its description of the dead, who, resurrected as creatures with perfect and imputrescible bodies, are immortal. Bacon claims that this is due to a perfect balance of elements.

To prepare the elixir, explains Bacon, one must use human blood that is divided into four basic humours:

The alchemist seeks to separate these humors from one another and to purge each from the other. When they have been led back to their pure 
simplicities by means of difficult works, then they should be mixed in a secret and most sure proportion. Quicksilver is added to them after it has been mortified and sublimed multiply. Likewise the calx or powder of the baser metal from which the nobler will be made. Likewise [calx of] the nobler. Then they should be incorporated together until they make one body. This is then projected onto the liquefied baser metal, and it thus becomes nobler. (Newman 1997: 331)

Heavenly influences had an important part to play when preparing the elixir. The elixir had to be taken outside at precise intervals, determined with the help of astrology, to be influenced by certain heavenly bodies; only then could the preparation process be completed. The effect of the elixir was by no means limited to the body, but also affected the mind and morals of a person. Bacon assures us that, "if this greatest thing can be done [the production of the elixir], it is evident that all other things are possible, namely that man might reach great foresight and perfect wisdom that he may know how to rule himself and others, with the help of the grace of God" (Matus 2017: 49).

It is possible to change a person completely with the help of the elixir, this being the true goal of alchemy.

Not only does the elixir guarantee a person knowledge of all sciences and secrets, but it also helps one to understand God and the truths of Christianity. Therefore, the result of the elixir is not only a perfect body but also a perfect Christian soul. Bacon believed that this human perfection opens up huge possibilities. Once an alchemist has become perfect himself, he can invent and construct devices to collect, copy, and transmit the same heavenly rays that were used to prepare the elixir. Bacon thought that huge mirrors had to be constructed so that those divine emanations could be transmitted to faraway lands. With the help of such emanations, it would be possible to change the complexion of these distant lands and the people living there, so that they would become Christian, or at least receptive to Christianity.

But why would all this be needed? Bacon's grandiose project acquires more meaning within its historical context, particularly with regard to doomsday. In Bacon's time, the end of the world was not a distant future: it was an upcoming reality that had to be taken into consideration on a daily basis. Bacon's letter to the Pope reads: "All wise men believe that we are not far removed from the times of Antichrist" (Bacon 1928: 417). Bacon was convinced that the sciences he was developing had a very important part to play in the doomsday battle with the antichrist. He believed that the antichrist also used science and the secrets of nature in his fight against Christians. He used alchemy, astrology, bewitching (the changing of a person's nature), and magic words. This was not simply a religious and a spiritual battle; all possible occult weapons were employed. 
With Bacon's elixir, it would have been possible to increase Christendom to a significant extent. Slow missionary work would have been replaced by changing the complexion of nations and regions, thereby making them receptive to the Word of God. Such a large-scale Christianising would have brought all nations under the rule of the Church and helped create an army to fight the antichrist. Bacon hoped that the Pope would implement the scientific and education programme that he had presented. However, in 1268, Pope Clement IV died and Bacon's programme elicited little interest from the church. It might have even been that his views were condemned, and he was accused of spreading "certain suspicious novelties". It is not known whether he was officially charged, but in 1278 he left Oxford for Paris. Bacon's attempt to create a Christian alchemy that would help the Church in the doomsday battle had failed.

\section{DISCUSSION}

The relationship between transhumanism and religion is complex. The central ideas of transhumanism are related to overcoming the biological limits of the human being, prolonging lifespans, and finally achieving immortality and bliss. Parallels to different religions are obvious. Generally, transhumanists themselves do not admit this connection, or at least do not consider it important (Noble 1997; Campbell \& Walker 2005; Maher \& Mercer 2009; Hopkins 2005; Bainbridge 2005). Even if religion is seen as the initial source of transhumanist ideas, a very clear border is drawn between them:

Transhumanists seek to make their dreams come true in this world, by relying not on supernatural powers or divine intervention but on rational thinking and empiricism, through continued scientific, technological, economic, and human development. (Bostrom 2003)

Some Christian theologians are very critical of transhumanism (Waters 2006). On the other hand, others try to interpret some transhumanist ideas in light of Christian theology (Hefner 2003; Peters 1996, 1997, 2003).

Transhumanist thinkers find their origins in eighteenth-century Europe, the Age of Enlightenment. As Bostrom claims that rational humanism emphasises "empirical science and critical reason - rather than revelation and religious authority - as ways of learning about the natural world and our place within it and of providing a grounding for morality. Transhumanism has roots in rational humanism" (Bostrom 2005: 3).

This is undoubtedly true, but at the same time what is not considered is the fact that the ideas of the Enlightenment were based on the earlier hermetic 
and religious schools of thought (Merchant 1980; Shapin \& Schaffer 1985; Dobbs 1975), one of which was alchemy. The most general goal of both alchemy and transhumanism is to change the world, although the aims and methods of achieving this goal might differ. Both traditions offer a theoretical framework and practical solutions. The central problem in both transhumanism and alchemy is the relationship between humans and nature, and the human capability to make nature artificial.

Transhumanism tries to overcome the opposition between nature and human culture: "if we reason in evolutionary rather than static terms, transhumanism cannot be considered as 'unnatural'. We are rather trying to establish a new harmony between culture and nature" (Campa 2008). To minimise this difference, transhumanism draws on technology, just as the alchemists did. Bacon found that the power of science surpassed even the forces of nature: "Now, although nature is powerful and marvellous, yet art using nature as an instrument is more powerful than natural strength, as we see in many things" (Bacon 1618: 21). In this sense, the prolongation of human life had a special significance: "But the ultimate degree to which art complements all the power of nature is the prolongation of human life over a long time. Many experiments show that this is possible" (Bacon 1618: 47). Bacon, like most alchemists, did not claim that humans would be capable of creating completely new creatures and species that did not already exist in nature. Alchemists tried to achieve the same results as nature by accelerating natural processes, thereby making nature more complete. Additionally, the methods used by alchemists were based on natural processes (Newman 2004: 292). Transhumanism pushes the limits of human capacity much further.

In our terms, Bacon's project was largely theoretical; it is most probable that he never tried to prepare the alchemic elixir. Similarly, the majority of transhumanist ideas, other than leading a healthy lifestyle and consuming food supplements, are still theoretical. In both cases, what is important is to prove the theoretical possibility, and not the immediate, practical implementation. If the elixir was an important part of the divine plan, as Bacon claimed, then its practical implementation would have been inevitable. The general aim of Roger Bacon's project was to assist in carrying out the divine plan of redemption. The broad transhumanist vision is also related to apocalyptic predictions: that is, predictions of technological singularity, soon to arrive.

The idea of technological singularity is based on the accelerating change argument, which extrapolates future technological and economic development. In brief, the idea is the following: history has shown us that technological development has been accelerating constantly and it is very likely that it will also accelerate over the next couple of decades. If this is the case, the changes 
that technological development will bring about in society, the economy, the biological nature of humans and their way of thinking are so deep that there will be a rupture in historical development, which has so far been constant. This rupture has been called a singularity, a name that refers to cosmology.

It is clear that Bacon did not manage to create an elixir that would have changed people into perfect immortal Christians. In his works, he presented the theoretical justification for preparing such an elixir and the instruction for its preparation. Why did he not prepare the elixir then and remove all doubt? Because it was the theoretical possibility of the elixir that mattered to Bacon. Its practical preparation in the current world held no importance. The elixir was intended to work in a world that had not yet come into being. The elixir was an imagination of the world as it should be, as well as a tool to achieve such a world. This was a tool for the end of the world, and since it was a Christian tool, it was inevitable that it would work once the apocalypse arrived. It was an inevitable realisation of a possible work, since this was how God had arranged it.

According to Bacon and also other alchemists, humans and their activities were part of God's plan. The largest difference between Bacon's views and transhumanism is the fact that Bacon based his theories on the Christian worldview and cosmology. Transhumanism, however, is a clearly scientific project. Nevertheless, it is also largely based on Christian eschatology, although it treats the perfection of humans mainly from the scientific and the technological points of view. One expression of this is the fact that the development of transhumanist ideas has increasingly led to an association with religion. The Mormon Transhumanist Association, which was established in 2006, is a good example of successful integration of transhumanist ideas in a mainstream religion (Cannon 2017). A Christian Transhumanist Association discussion group was launched online in November 2013 and the organisation was formally established in 2014 (CTA n.d.). In addition to transhumanist tendencies in existing religions, independent transhumanist religious movements have emerged, such as the Turing Church or the digitalism movement. The problems associated with Christian eschatology are inherited to transhumanism. Is human nature related to body or soul? Is the resurrection physical or spiritual?

Like transhumanism, mediaeval alchemy was also a borderline phenomenon. There were constant doubts about whether it was getting too close to the limits that God had set on humans, whether the alchemist with his practices was not trying to play God. The same claims are now being made about transhumanist ideas (Coady 2009). One of the most significant critics of transhumanist ideas is Francis Fukuyama, who was a member of the US President's Council on Bioethics between 2002 and 2005. Fukuyama favours strict national regulation of new biotechnologies and finds that new technologies pose a threat to 
human nature. He defines human nature as "the sum of the behaviour and characteristics that are typical of the human species, arising from genetics rather than environmental factors" (Fukuyama 2002: 130). He also emphasises the importance of language, consciousness, and emotions in defining a human being. According to him, such "constant human nature" is the foundation to liberal democracy. Therefore, new biotechnologies that might change human nature also pose a threat to the Western political and economic system.

Alchemy has always been associated on the one hand with the techno-chemical practice of the time (chemical technology since the seventeenth century) and on the other hand with philosophical and religious views of nature. Before the eighteenth century, alchemy and chemistry were basically indistinguishable; considering alchemy to be radically different from science is a later position. Bacon's alchemical project was based on the scientific foundations of the time, just as transhumanism relies on modern science.

Transhumanism can be seen as a continuation of an alchemical project in the twenty-first century. Modern science has added new tools to realise the goal of alchemical perfection. Transhumanism characterises very well the fact that the practices and theories of alchemy changed over time and adapted to changed contexts.

\section{CONCLUSIONS}

Treatment of transhumanism is very important as it places us in the middle of cultural and social problems that have been caused by the rapid development of science and technology over the past century. The transhumanist treatment of the future development of humans as a biological species has been significantly affected by previous schools of thought. Despite the fact that several transhumanist theoreticians treat it as a secular alternative to religious ideas, we can see that Christian eschatology plays a major role. Both in alchemy and transhumanism, scientific and theological aspects have been inseparably intertwined. Transhumanism has obvious connections to alchemical ideas. However, when it comes to such comparisons, it is important to keep in mind that, although there is a general continuity of Western ideas, the huge differences in historical context must be taken into consideration. After all, transhumanism interprets ideas originating from previous times based on the contemporary cultural context and the needs of our contemporary society.

The rebirth of mankind is important both to Bacon and transhumanists, but its essence is rather different. For Bacon, the transformation of mankind is first and foremost a moral process that does involve alchemical technology although is still meant to evoke spiritual change in humans. Bacon's programme provides 
a clear answer here: perfection can only mean changing humans and the world as a whole, encompassing the body, thought, soul, and culture. Whether technology is capable of this, no matter how developed it is, is highly questionable. The transhumanist understanding of human nature is overly simplistic: moral and cultural aspects are of relatively secondary concern (Ranisch 2014). The transhumanist vision of the end of the world and mankind as we know it, the technological singularity, is thoroughly materialistic and secular. According to Roger Bacon's alchemical treatment, a human being was something beyond body and mind. The end of the world was not only about perfection and resurrection of humans; these were necessary prerequisites for moral and spiritual rebirth, which should be treated not from the human but from the divine perspective. Bacon recognises the potential of mankind, its opportunity for development and importance in the development of the entire universe. Mankind has an important role to play once doomsday arrives. Both Bacon and transhumanist thinkers find that the world has a goal. For Bacon, the goal lies in God; for transhumanists, in the mind and desires of humans themselves.

\section{NOTES}

$1 \mathrm{H}+$, that is, enhanced humanity.

2 This article will not discuss the ideas of cultural posthumanists, which are more related to philosophy, cultural studies, criticism of modernism, feminism, postcolonialism and other approaches (see Tirosh-Samuelson \& Mossman 2011: 35).

3 Ectogenesis is creating and sustaining life in an artificial environment.

4 The term extropy was coined by Max More as a substitute for the more technical term negentropy, to denote negative entropy.

5 On defining alchemy, see Principe \& Newman 2001.

6 To provide an overview of Roger Bacon's life, I have used Power 2012.

7 For Bacon's works, see Bacon 1859 and Bacon 1897.

8 On Bacon's elixir, see Matus 2017.

\section{REFERENCES}

Antolic-Piper, Pia n.d. Roger Bacon (1214-1292). Internet Encyclopedia of Philosophy. Available at https://iep.utm.edu/bacon-ro/, last accessed on 3 December 2020.

Bacon, Roger 1597. The Mirror of Alchimy. London: Printed for Richard Oliue. Available at https://ia800500.us.archive.org/35/items/mirrorofalchimy00baco/ mirrorofalchimy00baco.pdf, last accessed on 2 December 2020. 
Bacon, Roger 1618. Epistola de secretis operibus artis et naturae. Hamburgi: Ex Bibliopolio Frobeniano. Available at https://reader.digitale-sammlungen.de//resolve/display/ bsb10912588.html, last accessed on 3 December 2020.

Bacon, Roger 1683. The Cure of Old Age and Preservation of Youth by Roger Bacon. Transl. by Richard Browne. London: Printed for Tho, Flesher and Edward Evets. Available at https://quod.lib.umich.edu/e/eebo/A28790.0001.001/1:6.7.1?rgn=div 3; view=toc, last accessed on 3 December 2020.

Bacon, Roger 1859. Opera Quaedam Hactenus Inedita, Vol. I: Opus Tertium, Opus Minus, Compedium Philosophiae. Edited by J.S. Brewer. London: Eyre \& Spottiswoode for Longman, Green, Longman, and Roberts. Available at http://gallica.bnf.fr/ ark:/12148/bpt6k50167j/f7.image, last accessed on 3 December 2020.

Bacon, Roger 1897. The "Opus Majus" of Roger Bacon: Edited, with Introduction and Analytical Table by John Henry Bridges. Vol I and Vol. II. Oxford: Horace Hart for the Clarendon Press. Available at https://archive.org/stream/ opusmajusofroger01baco\#page/n3/mode/2up and https://archive.org/stream/ opusmajusofroger02bacouoft\#page/n5/mode/2up, last accessed on 3 December 2020.

Bacon, Roger 1912. Part of the Opus tertium of Roger Bacon, including a fragment now printed for the first time. Aberdeen: The University Press. Available at https:// archive.org/details/partofopustertiu04baco, last accessed on 3 December 2020.

Bacon, Roger 1928. The Opus Majus of Roger Bacon. Vol I. Transl. By Robert Belle Burke. Philadelphia: University of Pennsylvania Press.

Bainbridge, William Sims 2005. The Transhuman Heresy. Journal of Evolution and Technology, Vol. 14, No. 2, pp. 91-100. Available at http://jetpress.org/volume14/ bainbridge.pdf, last accessed on 9 December 2020.

Bostrom, Nick 2003. The Transhumanist FAQ: A General Introduction. Version 2.1. Available at https://www.nickbostrom.com/views/transhumanist.pdf, last accessed on 3 December 2018.

Bostrom, Nick 2005. A History of Transhumanist Thought. Available at https://www. nickbostrom.com/papers/history.pdf, last accessed on 3 December 2020.

Cady, Linell E. 2011. Religion and the Technowonderland of Transhumanism. In: Hava Tirosh-Samuelson \& Kenneth L. Mossman (eds.) Building Better Humans? Refocusing the Debate on Transhumanism. Frankfurt am Main: Peter Lang GmbH, pp. 83-104.

Campa, Ricardo 2008. Italian Transhumanist Manifesto. 29 July. Available at https:// archive.ieet.org/articles/campa20080722.html, last accessed on 9 December 2020.

Cannon, Lincoln 2017. A Brief History of the Mormon Transhumanist Association. Available at: https://incoln.metacannon.net/2017/04/a-brief-history-of-mormontranshumanist.html, last accessed on 3 December 2020.

Campbell, Heidi \& Walker, Mark 2005. Religion and Transhumanism: Introducing a Conversation. Journal of Evolution and Technology, Vol. 14, No. 2, pp. i-xv. Available at https://www.academia.edu/697912/Religion_and_transhumanism_ introducing_a_conversation, last accessed on 9 December 2020.

Clay, Eugene 2011. Transhumanism and the Orthodox Christian Tradition. In: Hava Tirosh-Samuelson \& Kenneth L. Mossman (eds.) Building Better Humans? Refocusing the Debate on Transhumanism. Frankfurt am Main: Peter Lang GmbH, pp. 157-180. 
Coady, Cecil Anthony 2009. Playing God. In: Julian Savulescu \& Nick Bostrom (eds.) Human Enhancement. Oxford: Oxford University Press, pp. 155-180.

CTA n.d. = The History of the Christian Transhumanist Association. Available at: https:// www.christiantranshumanism.org/history, last accessed on 3 December 2020.

Dobbs, Betty Jo Teeter 1975. The Foundations of Newton's Alchemy. Cambridge: Cambridge University Press.

Ferkiss, Victor C. 1969. Technological Man: The Myth and the Reality. New York: Mentor Books.

Fukuyama, Francis 2002. Our Posthuman Future: Consequences of the Biotechnology Revolution. London: Profile.

Gruman, Gerald J. 2003 [1966]. A History of Ideas about the Prolongation of Life. New York: Springer.

Haldane, John Burdon Sandreson 1924. Daedalus, or Science and the Future. London: Kegan Paul, Trench, Trubner \& Co.

Hefner, Philip 2003. Technology and Human Becoming. Minneapolis, MN: Fortress.

Hopkins, Patrick D. 2005. Transcending the Animal: How Transhumanism and Religion Are and Are Not Alike. Journal of Evolution and Technology, Vol. 14, No. 2, pp. 13-28. Available at http://jetpress.org/volume14/hopkins.pdf, last accessed on 4 December 2020.

Hughes, James 2004. Citizen Cyborg: Why Democratic Societies Must Respond to the Redesigned Human of the Future. Boulder, CO: Westview Press.

Huxley, Julian 1957. Transhumanism. In: New Bottles for New Wine: Essays by Julian Huxley. London: Chatto \& Windus, pp. 13-17. Available athttps://archive.org/details/ NewBottlesForNewWine/page/n15/mode/2up, last accessed on 4 December 2020. Krueger, Oliver 2005. Gnosis in Cyberspace? Body, Mind and Progress in Posthumanism. Journal of Evolution and Technology, Vol. 14, No. 2, pp. 77-89. Available at http:// jetpress.org/volume14/krueger.pdf, last accessed on 4 December 2020.

Maher, Derek F. 2014. Buddhism: The Transformed Body in Buddhism. In: Derek F. Maher \& Calvin Mercer (eds.) Transhumanism and the Body: The World Religions Speak. New York: Palgrave Macmillan, pp. 19-34.

Maher, Derek F. \& Mercer, Calvin (eds.) 2009. Religion and the Implications of Radical Life Extension. New York: Palgrave Macmillan.

Mahootian, Farzad 2011. Ideals of Human Perfection: A Comparison of Sufism and Transhumanism. In: Hava Tirosh-Samuelson \& Kenneth L. Mossman (eds.) Building Better Humans? Refocusing the Debate on Transhumanism. Frankfurt am Main: Peter Lang GmbH, pp. 133-156.

Maslow, Abraham 1971. The Farther Reaches of Human Nature. New York: Penguin Books. Matus, Zachary A. 2017. Franciscans and the Elixir of Life: Religion and Science in the Later Middle Ages. Philadelphia: University of Pennsylvania Press.

Mavani, Hamid 2014. Islam - God's Deputy: Islam and Transhumanism. In: Derek F. Maher \& Calvin Mercer (eds.) Transhumanism and the Body: The World Religions Speak. New York: Palgrave Macmillan, pp. 67-83.

Merchant, Carolyn 1980. The Death of Nature: Women, Ecology, and the Scientific Revolution. New York: Harper \& Row.

Newman, William R. 1997. An Overview of Roger Bacon's Alchemy. In: Jeremiah Hackett (ed.) Roger Bacon and the Sciences: Commemorative Essays. Leiden: Brill, pp. 317-336. 
Newman, William R. 2004. Promethean Ambitions: Alchemy and the Quest to Perfect Nature. Chicago: University of Chicago Press.

Noble, David F. 1997. The Religion of Technology. New York: Knopf.

Peters, Ted 1996. For the Love of Children: Genetic Technology and the Future of the Family. Louisville, KY: Westminster Knox Press.

Peters, Ted 1997. Playing God? Genetic Determinism and Human Freedom. New York: Routledge.

Peters, Ted 2003. Science, Theology and Ethics. Aldershot, UK \& Burlington, VT: Ashgate.

Power, Amanda 2012. Roger Bacon and the Defence of Christendom. Cambridge: Cambridge University Press.

Principe, Lawrence M. 2013. The Secrets of Alchemy. Chicago \& London: The University of Chicago Press.

Principe, Lawrence M. \& Newman, William R. 2001. Some Problems with the Historiography of Alchemy. In: William R. Newman \& Anthony Grafton (eds.) Secrets of Nature: Astrology and Alchemy in Early Modern Europe. Cambridge, MA: The MIT Press, pp. 385-431.

Pugh, Jeffrey C. 2017. The Disappearing Human: Gnostic Dreams in a Transhumanist World. Religions, Vol. 8, No. 5. http://dx.doi.org/10.3390/rel8050081.

Ranisch, Robert 2014. Morality. In: Robert Ranisch \& Stefan Lorenz Sorgner (eds.) Post- and Transhumanism: An Introduction. Frankfurt am Main: Peter Lang, pp. 149-172.

Samuelson, Norbert \& Tirosh-Samuelson, Hava 2011. Jewish Perspectives on Transhumanism. In: Hava Tirosh-Samuelson \& Kenneth L. Mossman (eds.) Building Better Humans? Refocusing the Debate on Transhumanism. Frankfurt am Main: Peter Lang GmbH, pp. 105-132.

Shapin, Steven \& Schaffer, Simon 1985. Leviathan and the Air Pump: Hobbes, Boyle and the Experimental Life. Princeton, NJ: Princeton University Press.

Smith, Neil 1996. The Production of Nature. In: George Robertson \& Melinda Mash \& Lisa Tickner \& Jon Bird \& Barry Curtis \& Tim Putnam (eds.) FutureNatural: Nature, Science, Culture. London \& New York: Routledge, pp. 35-54.

Tirosh-Samuelson, Hava \& Mossman, Kenneth L. 2011. New Perspectives on Transhumanism. In: Hava Tirosh-Samuelson \& Kenneth L. Mossman (eds.) Building Better Humans? Refocusing the Debate on Transhumanism. Frankfurt am Main: Peter Lang GmbH, pp. 29-52.

Transhumanist Declaration. Available at https://humanityplus.org/philosophy/ transhumanist-declaration/, last accessed on 4 December 2020.

Waters, Brent 2006. From Human to Posthuman: Christian Theology and Technology in a Postmodern World. Aldershot, UK \& and Burlington, VT: Ashgate.

Kurmo Konsa is Associate Professor at the Department of Archival Studies at the University of Tartu, and Professor of Conservation at Pallas University of Applied Sciences. His main fields of interests are the preservation and conservation of cultural heritage, and the history of alchemy.

kurmo.konsa@ut.ee 